\title{
Some Biochemical Parameters as a Simple Tool for the Prediction of Severity of Scorpion Envenomation among Some Egyptian Children
}

\author{
Gihan B. Azab and Eglal H. ELawady ${ }^{1}$ \\ ${ }^{1}$ Department of Forensic Medicine and Clinical Toxicology, Faculty of Medicine, Ain Shams University, Cairo,
Egypt.
}

\begin{abstract}
BACKGROUND: Scorpion sting envenomation is a common public health problem in Egypt and life-threatening emergency, particularly in children. They are at greater risk of developing severe cardiac, respiratory, and neurological complications. Early evaluation of the severity of the envenomation is essential to institute adequate treatments and prevent mortality. AIM: The aim of this study was to assess the value of some routine biochemical parameters in the prediction of severity of scorpion envenomation among some Egyptian children. METHODS: A prospective observational study was conducted on all scorpion envenomated children, admitted to the poison control centre , Ain shams university hospitals from January to December 2015. On admission, all the children with envenomation were subjected to complete medical history, physical examination and routine biochemical laboratory tests. The patients were classified in to three main groups, according to the degree of severity; Group II (mild grade); Group III (moderate grade) and Group IV (severe grade). In addition, ten apparently healthy children were included as a control group (Group I). RESULTS: there were 25 patients (41.6\%) in group II, 20 patients (33.4\%) in group III and 15 patients (25\%) in group IV. The mean age and body weight were significantly decreased in groups III and IV, being lower in group IV. The mean delay time between sting and hospital admission was significantly longer for group IV compared with group III followed by group II. The frequency of stings in lower limb (68\%) was significantly higher than those on the upper limb (32\%) in group II. It was significantly higher in upper limb than lower limb in groups III and IV. Clinically, the most common finding was severe pain at sting site in all studied groups. Furthermore, the results of patients in group IV were significantly higher when compared with group III as regards: the general manifestations (sweating, fever and cold extremities); respiratory manifestations (tachypnea, cyanosis and pulmonary edema); cardiac manifestations (hypertension, tachycardia and heart failure); neurological manifestations (agitation and coma) and gastrointestinal manifestations (vomiting and abdominal pain). The mean values of random glucose level, total WBC and platelet counts were significantly higher in groups III and IV when compared with control group, being higher in group IV when compared with group III. The mean values of CK-MB level were significantly higher in group IV when compared with control group. In severe cases (group IV), Platelet counts showed a significant positive correlation with WBC count, and CKMB level values, In addition WBC count showed a significant positive correlation with CK-MB level. While glucose level showed insignificant correlation with CK-MB level, WBC and platelet counts. The mean duration of hospital stay was significantly longer in group IV compared with groups II and III. All the patients discharged with complete recovery with no morbidity or mortality. CONCLUSION: Increased levels of on admission glucose, CK-MB, total WBC and platelets count were more obvious in severely envenomated cases. Increased platelet, total WBC count and CK-MB level were found to be predictors of severe envenomation.
\end{abstract}




\section{Introduction}

$\mathrm{S}$ corpion envenomation is common in tropical and subtropical regions. In Egypt, it is still representing a medical problem and is considered an acute life-threatening condition (Mohamad et al., 2014). Buthidae and Scorpionidae are the most common and lethal scorpion families found abundantly in different regions in Egypt. The largest member found among Buthidae family is the fat tail scorpion, which is one of the most dangerous groups in the world with very potent venom. Envenomation can cause various neuro-muscular and cardio-vascular toxic effects, which may result in death (Wesam and Khadega, 2013).

The toxic effects of scorpion envenomation are due to a massive release of sympathetic and para-sympathetic neurotransmitters. The severity is related to cardiac and hemodynamic changes, with cardiogenic shock and pulmonary edema contributing to the main causes of death (Cupo, 2015).

It has been found that many factors can affect the clinical severity of envenomation, which includes the age and body weight of the victim. Therefore, children exhibit more severe symptoms and have a considerably increased mortality rate compared with adults (Bosnak et al., 2009; Bahloul et al., 2010). In endemic regions, early evaluation of the severity of the envenomation, particularly in children, is essential to institute adequate treatments and prevent mortality.

So the aim of this study is to assess the value of some routine biochemical parameters in the prediction of severity of scorpion envenomation among some Egyptian children.

\section{Patients and methods}

\section{Patients}

A prospective observational study was conducted on all scorpion envenomated children, less than 18 years, admitted to the Poison Control Centre; Ain Shams University Hospitals (PCC-ASUH), from January to December 2015. The diagnosis of scorpion envenomation was based on a history of scorpion sting.

Exclusion criteria: any patient with previous history of liver, renal, pulmonary, neurological, haematological, or heart disease. In addition to patients with diabetes, allergic conditions or infectious disease.

An informed written consent was taken from his/her legal guardian in addition to head of PCC and ethical committee approval.

\section{Methods}

On admission, all the children with envenomation were subjected to complete medical history, physical examination and biochemical laboratory investigations.

$>$ Medical history: age, gender, site of the sting and delay time (time interval from envenomation to arrival to hospital).

> Physical examination:

- Body weight.

- Local examination of sting site.

- General manifestations: sweating, cyanosis, priabism and cold extremities.

- Vital data: pulse, blood pressure, temperature and respiratory rate. Abnormal values were defined according to normal values for age group (Hartman and Cheifetz, 2011).

- Respiratory examination: acute pulmonary edema; diagnosis based on the presence of:

- Clinical signs of respiratory distress (tachypnea and inspiratory retraction of intercostal spaces).

- Lung crackles on auscultation of one or both lungs.

- The presence of arterial hypoxemia. In patients receiving mechanical ventilation, arterial hypoxemia was defined as a $\mathrm{PaO}_{2} / \mathrm{FiO}_{2}$ ratio $<300$.

- Signs of interstitial and/or alveolar pulmonary edema on the chest X-ray (Bahloul et al., 2013).

- Cardiovascular manifestations: dysrhythmia, heart failure (presented clinically with tachycardia, gallop rhythm, muffled heart sounds and at least one of the following: ECG changes, cardiac dysfunction on echocardiography or increased cardiac enzyme Creatine kinase myocardial band (CK-MB) level (Canter and Simpson, 2014).

- Neurological examination: Pupil size and reactivity, agitation, seizures, level of consciousness (assessed by Glasgow coma scale) (Reith et al., 2016).

- Gastro-intestinal manifestations: vomiting, diarrhea, abdominal pain.

Ten apparently healthy children of matched age and sex were included as a control group (Group I). The patients were classified into three main groups, according to the degree of severity of envenomation, on admission. Group II (mild grade) presented with local signs included: local pain, erythema and paresthesia restricted to the sting area. Group III (moderate grade) included 
patients with local and mild systemic findings. Group IV (severe grade) included patients with severe systemic manifestations, such as cardiogenic shock, myocarditis, pulmonary edema, altered consciousness and convulsion (Nouira et al., 2007; Bosnak et al., 2009).

\section{Biochemical investigations:}

The routine laboratory investigations were done on admission for all the studied patients, including:

- Random blood glucose level. Done by calorimetric method (Kaplan, 1984).

- $\quad$ Serum electrolytes levels: sodium $\left(\mathrm{Na}^{+}\right)$ and potassium $\left(\mathrm{K}^{+}\right)$were determined by flame absorption photometer JenwayPFP7 (Bibby Scientific Limited OSA, UK) (Rothrock et al., 1997).

- Cardiac enzyme: Creatine kinase myocardial band (CK-MB) level was measured via an enzymatic method (Biochemical auto analyzer) (Mair et al., 1991). (Thermo fisher scientific, USA).

- Kidney function: blood urea nitrogen (BUN) and serum creatinine were measured by colorimetric method (Lawrence and Robert, 1993).

- Liver enzymes: aspartate aminotransferase (AST), alanine aminotransferase (ALT) were determined by colorimetric method (Suber, 1994).

- Haematological tests: [Red blood cell count (RBC), Haemoglobin concentration (Hb), total white blood cell count (WBC) and platelet count] using coulter counter model M450 [coulter Electronics Ltd, Australia].

All patients received standard medical treatment. This followed an approved standard protocol, which was dictated by the patient's clinical condition. The protocol included hospital admission. Patients with no systemic manifestations were sent to the intermediate care unit for observation. Patients with moderate and severe envenomation were transferred to the intensive care unit. Anti-venom, inotropic drugs, intubation and mechanical ventilation were given if indicated (Cupo, 2015).

$>$ Outcome data: duration of stay in hospital, mode of discharge (complete recovery, morbidity or mortality).

\section{Statistical analysis}

The results were statistically analyzed using the SPSS software, version 15 (SPSS, Inc., Chicago, IL). Quantitative data are described as Mean \pm SD. ANOVA one way statistical analysis and Chi- square test were used to compare between the groups. The Pearson's correlation coefficient was used to assess the relationship between laboratory values and clinical severity. $\mathrm{P}$ values $<0.05$ were considered statistically significant (Taylor, 1990).

\section{Results}

Sixty patients were included in the present study. Their mean age was $(85 \pm 23)$ months. They were categorized into three groups according to the severity of scorpion envenomation.

Medical history data of the patients: Table 1 shows that there were 25 patients (41.6\%) in mild grade (group II), 20 patients (33.4\%) in moderate grade (group III) and 15 patients (25\%) in the severe grade (group IV).

As regards age and body weight group II revealed insignificant difference when compared with the control group (group I), while there was a significant decrease in groups III and IV. By applying confidence limit (CL) the mean age and body weight of the children in group IV were significantly lower than that of group III.

The mean delay time between sting and hospital admission was significantly longer for the group IV compared with the group III followed by group II.

As regards the gender, table 2 shows that there was insignificant difference between male and female ratio per group. In group II the frequency of stings in lower limb (68\%) was significantly higher than those on the upper limb (32\%). While the frequency of stings in upper limb was significantly higher than those on the lower limb in groups III and IV. One patient in group IV showed a sting in the forehead.

The majority of stings in all groups occurred between April and October (histogram 1).

The clinical manifestations: Table 3 shows that the most common finding was severe pain at sting site in the studied groups. Furthermore, the results of patients in group IV were significantly evident when compared with group III as regards: the general manifestations (sweating, fever and cold extremities); respiratory manifestations (tachypnea, cyanosis and pulmonary edema); cardiac manifestations: (hypertension, tachycardia and heart failure); neurological manifestations (agitation and coma) and gastrointestinal manifestations (vomiting and abdominal pain).

Biochemical parameters: Table 4 shows a comparison of the levels of random blood glucose, $\mathrm{Na}^{+}, \mathrm{K}^{+}$and $\mathrm{CK}-\mathrm{MB}$ on admission between all tested groups and control group (group 
I). There was insignificant difference in all parameters when group II compared with the control group.

As regards groups III and IV, glucose levels were significantly high when compared with control group, being higher in group IV. There was insignificant difference of $\mathrm{Na}^{+}$and $\mathrm{K}^{+}$levels when compared with the control group. CK-MB mean level was significantly high in group IV when compared with the control group.

Regarding kidney functions on admission (BUN and serum creatinine) and liver enzymes [AST, ALT)] levels, there was insignificant difference between the levels in all groups when compared with the control group (tables 5 and 6).

Concerning on admission haematological parameters [RBC, haemoglobin concentration $(\mathrm{Hb})$, total WBC and platelet counts] (table 7), there was insignificant difference in group II when compared with control group (group I). Moreover there was insignificant difference on comparing $\mathrm{RBC}$ and $\mathrm{Hb}$ levels in groups III and IV with the control group. While, a significant increase of total WBC and platelet counts was found in groups III and IV when compared with the control group. By applying CL they were significantly higher in group IV than group III.

Table 8 shows that in severe group, mean platelet counts showed a significant positive correlation with mean total WBC count, and CKMB level values. In addition total WBC count showed a significant positive correlation with mean CK-MB level. While mean random glucose level showed insignificant correlation with platelet, total WBC counts and CK-MB level.

Outcome results : Tables $9 \& 10$ show that the mean duration of hospital stays were significantly longer in group IV compared with groups II and III. All the patients discharged with complete recovery with no morbidity or mortality.

Table 1: ANOVA, one way Statistical Analysis of age, body weight, delay time among scorpion stung patients groups II (mild grade), group III (moderate grade), group IV (severe grade) and the control group (group I).

\begin{tabular}{|l|l|l|l|l|l|l|}
\hline & \multicolumn{1}{|c|}{$\begin{array}{c}\text { Group I } \\
(\mathbf{n = 1 0})\end{array}$} & $\begin{array}{c}\text { Group II } \\
(\mathbf{N}=\mathbf{2 5})\end{array}$ & $\begin{array}{c}\text { Group III } \\
\mathbf{( N = 2 0 )}\end{array}$ & Group IV (n=15) & Fc & CL \\
\hline Age (months) $(\mathrm{M} \pm \mathrm{SD})$ & $122 \pm 40.3$ & $120.5 \pm 12.8$ & $79.2 \pm 10.6^{*}$ & $44.2 \pm 9.4^{*} \#$ & 17 & 25.41 \\
\hline $\begin{array}{l}\text { Body weight }(\mathrm{kg}) \\
(\mathrm{M} \pm \mathrm{SD})\end{array}$ & $30.54 \pm 5.2$ & $29.9 \pm 4.7$ & $24.1 \pm 3.2^{*}$ & $16.8 \pm 1.2^{*} \#$ & 42.6 & 2.64 \\
\hline $\begin{array}{l}\text { Delay time (hours) } \\
(\mathrm{M} \pm \mathrm{SD})\end{array}$ & - & $2.5 \pm 0.5$ & $3.2 \pm 0.6$ & $4.5 \pm 1.2 \#$ & 84.8 & 0.45 \\
\hline
\end{tabular}

$(M \pm S D)=$ mean \pm standard deviation, $F c=$ calculated variance ratio, $F t=$ tabulated variance ratio $=3.732$, $C L=$ confidence limit. $* P<0.05=$ significant difference compared with (group I). $\# P<0.05=$ significant difference compared with (group III).

Table 2: Chi square test $\left(\mathrm{X}^{2}\right)$ comparing gender and sting site, among scorpion stung patients: group II (mild grade), group III (moderate grade), group IV (severe grade) and the control group (group I).

\begin{tabular}{|c|c|c|c|c|}
\hline & $\begin{array}{c}\text { Group I } \\
(n=10)\end{array}$ & $\begin{array}{c}\text { Group II } \\
(\mathrm{N}=25)\end{array}$ & $\begin{array}{c}\text { Group III } \\
(\mathrm{N}=20)\end{array}$ & Group IV $(n=15)$ \\
\hline $\begin{array}{l}\text { Gender(male/female ratio) } \\
\mathbf{P}\end{array}$ & $\begin{array}{r}5 / 5 \\
>\mathbf{0 . 0 5}\end{array}$ & $\begin{aligned} & 13 / 12 \\
>\mathbf{0 . 0 5} & \end{aligned}$ & $\begin{array}{l}8 / 12 \\
>\mathbf{0 . 0 5}\end{array}$ & $>\mathbf{0 . 0 5} 5^{9 / 6}$ \\
\hline $\begin{array}{l}\text { Sting site } \\
\text { Upper limb } \\
\text { lower limb } \\
\text { head \& neck } \\
\mathbf{P}\end{array}$ & - & $\begin{array}{c}8 \quad(32 \%) \\
17(68 \%) \\
- \\
<\mathbf{0 . 0 5}\end{array}$ & $\begin{array}{c}14 \text { (70\%) } \\
6(30 \%) \\
- \\
<\mathbf{0 . 0 5}\end{array}$ & $\begin{array}{c}10(66.7 \%) \\
4(26.7 \%) \\
1(6.6 \%) \\
<\mathbf{0 . 0 5}\end{array}$ \\
\hline
\end{tabular}

$p>0.05=$ insignificant difference, $p<0.05=$ significant difference. 
Table 3: Chi square $\left(\mathrm{X}^{2}\right)$ test of clinical manifestations between group III (moderate grade) and group IV (severe grade) in scorpion stung patients.

\begin{tabular}{|c|c|c|c|}
\hline Clinical manifestations & $\begin{array}{l}\text { Group III } \\
(\mathrm{N}=20)(\%)\end{array}$ & Group IV (n=15) (\%) & $\mathbf{P}$ \\
\hline Local pain & $19(95 \%)$ & $15(100 \%)$ & $>0.05$ \\
\hline \multicolumn{4}{|c|}{ General manifestations } \\
\hline Sweating & $7(35 \%)$ & $13(86.7 \%)$ & $<0.01$ \\
\hline fever & $2(10 \%)$ & $10(66.7 \%)$ & $<0.001$ \\
\hline Priapism & $3(15 \%)$ & $4(26.7 \%)$ & $>0.05$ \\
\hline Cold extremities & $10(50 \%)$ & $13(86.7 \%)$ & $<0.05$ \\
\hline \multicolumn{4}{|c|}{ Respiratory manifestations } \\
\hline Tachypnea & $5(25 \%)$ & $15(100 \%)$ & $<0.001$ \\
\hline Cyanosis & $0(0 \%)$ & $13(86.7 \%)$ & $<0.001$ \\
\hline Pulmonary edema & $0(0 \%)$ & $13(86.7 \%)$ & $<0.001$ \\
\hline \multicolumn{4}{|c|}{ Cardiac manifestations } \\
\hline Hypertension & $3(15 \%)$ & $10(66.7 \%)$ & $<0.001$ \\
\hline hypotension & $0(0 \%)$ & $3(20 \%)$ & $>0.05$ \\
\hline tachycardia & $5(25 \%)$ & $13(86.7 \%)$ & $<0.001$ \\
\hline Heart failure & $0(0 \%)$ & $10(66.7 \%)$ & $<0.001$ \\
\hline \multicolumn{4}{|c|}{ Neurological manifestations } \\
\hline Agitation & $5(25 \%)$ & $13(86.7 \%)$ & $<0.001$ \\
\hline Bilateral mydriasis & $0(0 \%)$ & $3(20 \%)$ & $>0.05$ \\
\hline Coma & $0(0 \%)$ & $4(26.7 \%)$ & $<0.05$ \\
\hline \multicolumn{4}{|c|}{ Gastro-intestinal manifestations } \\
\hline Vomiting & $5(25 \%)$ & $12(80 \%)$ & $<0.001$ \\
\hline diarrhea & $0(0 \%)$ & $2(13 \%)$ & $>0.05$ \\
\hline Abdominal pain & $5(25 \%)$ & $14(93 \%)$ & $<0.001$ \\
\hline
\end{tabular}

$P>0.05=$ insignificant difference, $P<0.05$ significant difference, $P<0.001$ very high significant difference

Table 4: ANOVA, one way Statistical Analysis comparing on admission random blood glucose, plasma sodium $\left(\mathrm{Na}^{+}\right)$, potassium $\left(\mathrm{K}^{+}\right)$and Creatine kinase myocardial band (CK-MB) levels, among scorpion stung patients: group II (mild grade), group III (moderate grade), group IV (severe grade) and the control group (group I).

\begin{tabular}{|l|l|l|l|l|l|l|}
\hline \multicolumn{1}{|c|}{ parameters } & $\begin{array}{l}\text { Group I } \\
(\mathbf{n = 1 0 )}\end{array}$ & $\begin{array}{l}\text { Group II } \\
(\mathbf{N = 2 5 )}\end{array}$ & $\begin{array}{l}\text { Group III } \\
(\mathbf{N = 2 0 )}\end{array}$ & $\begin{array}{l}\text { Group IV } \\
(\mathbf{n = 1 5 )}\end{array}$ & Fc & CL \\
\hline Glucose $(\mathrm{mg} / \mathrm{dl})$ & $122.4 \pm 16.5$ & $124.4 \pm 17.4$ & $174.6 \pm 19.1^{*}$ & $317.8 \pm 33.4^{*} \#$ & 269 & 14.66 \\
\hline $\mathrm{Na}^{+} \mathrm{mEq} / \mathrm{L}$ & $142 \pm 33$ & $143 \pm 23$ & $141 \pm 37$ & $138 \pm 29$ & 0.08 & 122 \\
\hline $\mathrm{K}^{+} \mathrm{mEq} / \mathrm{L}$ & $3.49 \pm 0.05$ & $3.5 \pm 0.04$ & $3.45 \pm 0.16$ & $3.39 \pm 0.53$ & 0.6 & 1.05 \\
\hline $\mathrm{CK}-\mathrm{MB}(\mu \mathrm{g} / \mathrm{L})$ & $0.3 \pm 0.03$ & $0.3 \pm 0.01$ & $0.5 \pm 0.01$ & $22.7 \pm 4.5^{*}$ & 455 & 1.37 \\
\hline
\end{tabular}

The data represented as mean $\pm S D$ (standard deviation), $F c=$ calculated variance ratio, $F t=$ tabulated variance ratio 3.732, $C L=$ confidence limit. $* P<0.05=$ significant difference compared with (group $I)$. \#P<0.05= significant difference compared with (group III).

Table 5: ANOVA, one way Statistical Analysis comparing on admission kidney function tests[ blood urea nitrogen(BUN) and serum creatinine] levels , among scorpion stung patients: group II (mild grade), group III (moderate grade), group IV (severe grade) and the control group (group I).

\begin{tabular}{|l|l|l|l|l|l|l|}
\hline \multicolumn{1}{|c|}{ parameters } & $\begin{array}{l}\text { Group I } \\
(\mathbf{n = 1 0 )}\end{array}$ & $\begin{array}{l}\text { Group II } \\
(\mathbf{N = 2 5 )}\end{array}$ & $\begin{array}{l}\text { Group III } \\
(\mathbf{N = 2 0 )}\end{array}$ & $\begin{array}{l}\text { Group IV } \\
(\mathbf{n = 1 5})\end{array}$ & Fc & CL \\
\hline BUN (mg/dl) & $26.9 \pm 7.9$ & $29.0 \pm 8.5$ & $30.1 \pm 6.5$ & $32.1 \pm 8.2$ & 0.98 & 31.8 \\
\hline S.creatinine(mg/dl) & $0.49 \pm 0.02$ & $0.50 \pm 0.03$ & $0.51 \pm 0.03$ & $0.50 \pm 0.04$ & 1.14 & 0.124 \\
\hline
\end{tabular}

The data represented as mean $\pm S D$ (standard deviation), $F c=$ calculated variance ratio, $F t=$ tabulated variance ratio at $P$ 0.05=3.732, $C L=$ confidence limit. 
Table 6: ANOVA, one way Statistical Analysis comparing on admission liver enzymes [aspartate aminotransferase (AST), alanine aminotransferase (ALT)] levels, among scorpion stung patients :group II (mild grade), group III (moderate grade), group IV (severe grade) and the control group (group I).

\begin{tabular}{|l|l|l|l|l|l|l|}
\hline parameters & $\begin{array}{l}\text { Group I } \\
(\mathbf{n = 1 0 )}\end{array}$ & $\begin{array}{l}\text { Group II } \\
\mathbf{( N = 2 5 )}\end{array}$ & $\begin{array}{l}\text { Group III } \\
\mathbf{( N = 2 0 )}\end{array}$ & $\begin{array}{l}\text { Group IV } \\
(\mathbf{n = 1 5})\end{array}$ & Fc & CL \\
\hline AST(IU/L) & $33.24 \pm 5.02$ & $31.64 \pm 5.22$ & $32.24 \pm 4.02$ & $30.94 \pm 3.12$ & 0.95 & 18 \\
\hline ALT(IU/L) & $26.12 \pm 3.22$ & $25.53 \pm 3.42$ & $26.19 \pm 3.32$ & $25.6 \pm 5.5$ & 0.14 & 15.9 \\
\hline
\end{tabular}

The data represented as mean $\pm S D$ (standard deviation), $F_{C}=$ calculated variance ratio, $F t=$ tabulated variance ratio at $P$ 0.05=3.732, $C L=$ confidence limit.

Table 7: ANOVA, one way Statistical Analysis comparing on admission hematological parameters [Red Blood cell count (RBC), hemoglobin (Hb) level, total white blood cells count (WBC) and platelet counts], among scorpion stung patients groups II (mild grade), group III (moderate grade), group IV (severe grade) and the control group (group I).

\begin{tabular}{|l|l|l|l|l|l|l|}
\hline \multicolumn{1}{|c|}{ parameters } & $\begin{array}{c}\text { Group I } \\
(\mathbf{n}=\mathbf{1 0})\end{array}$ & $\begin{array}{c}\text { Group II } \\
(\mathbf{N}=\mathbf{2 5})\end{array}$ & $\begin{array}{c}\text { Group III } \\
\mathbf{( N = 2 0 )}\end{array}$ & Group IV (n=15) & \multicolumn{1}{|c|}{ FC } & \multicolumn{1}{c|}{ CL } \\
\hline $\mathrm{RBCs}\left(\mathrm{x} 10^{9} / \mathrm{ml}\right)$ & $4.44 \pm 0.48$ & $4.46 \pm 0.27$ & $4.56 \pm 0.47$ & $4.43 \pm 0.57$ & 0.34 & 1.77 \\
\hline $\mathrm{Hb}(\mathrm{g} / \mathrm{dl})$ & $12.9 \pm 2.4$ & $12.15 \pm 2.7$ & $12.95 \pm 1.9$ & $13.0 \pm 1.05$ & 0.74 & 8.8 \\
\hline $\mathrm{WBCs}\left(\mathrm{x} 10^{3} / \mathrm{ml}\right)$ & $6.12 \pm 1.13$ & $6.6 \pm 1.1$ & $10.7 \pm 1.3^{*}$ & $20.41 \pm 3.7^{*} \#$ & 154 & 1.33 \\
\hline Platelets $\left(\mathrm{x} 10^{3} / \mathrm{ml}\right)$ & $185 \pm 19.3$ & $191 \pm 12.7$ & $391 \pm 15.7^{*}$ & $441 \pm 17^{*} \#$ & 1231 & 10.31 \\
\hline
\end{tabular}

The data represented as mean $\pm S D$ (standard deviation), $F c=$ calculated variance ratio, $F t=$ tabulated variance ratio at $P$ 0.05=3.732, $C L=$ confidence limit. $* P<0.05=$ significant difference compared with (group I). $\# P<0.05=$ significant difference compared with (group III).

Table 8: Pearson's correlation between Platelets count, glucose level, total white blood cell count (WBC) and Creatine kinase myocardial band (CK-MB) levels in the severe group (group IV).

\begin{tabular}{|l|l|l|l|l|}
\hline \multirow{2}{*}{ Parameter $(\mathbf{M} \pm$ SD) } & Platelets $\mathbf{( x 1 0} / \mathbf{m l})$ & \multicolumn{1}{|c|}{$\begin{array}{c}\text { Glucose } \\
(\mathbf{m g} / \mathbf{d l})\end{array}$} & $\begin{array}{c}\text { WBC } \\
(\mathbf{x 1 0} / \mathbf{m l})\end{array}$ & $\begin{array}{c}\text { CK-MB } \\
(\boldsymbol{\mu g} / \mathbf{L})\end{array}$ \\
\cline { 2 - 5 } $\begin{array}{l}\text { Platelets }\left(\mathrm{x} 10^{3} / \mathrm{ml}\right) \\
(441 \pm 17)\end{array}$ & $(441 \pm 17)$ & $(317.8 \pm 33.4)$ & $(20.41 \pm 3.7)$ & $(22.7 \pm 4.5)$ \\
\hline $\begin{array}{l}\text { Glucose }(\mathrm{mg} / \mathrm{dl}) \\
(317.8 \pm 33.4)\end{array}$ & $\mathrm{r}=0.1$ & & \\
\hline $\begin{array}{l}\text { WBC }\left(\mathrm{x} 10^{3} / \mathrm{ml}\right) \\
(20.41 \pm 3.7)\end{array}$ & $\mathrm{P}>0.05$ & 1 & & \\
\hline $\begin{array}{l}\text { CK-MB }(\mu \mathrm{g} / \mathrm{L}) \\
22.7 \pm 4.5\end{array}$ & $\mathrm{p}<0.8$ & $\mathrm{r}=0.04$ & 1 & \\
\hline
\end{tabular}

Data presented as Mean $\pm S D$, " $r$ ": correlation coefficient, $P>0.05$ : insignificant correlation. $P<0.001$ : very high significant positive correlation.

Table 9: ANOVA, one way Statistical Analysis comparing duration of hospital stay among scorpion stung patients: group II (mild grade), group III (moderate grade), group IV (severe grade) and the control group (group I).

\begin{tabular}{|l|l|l|l|l|l|l|}
\hline & $\begin{array}{l}\text { Group I } \\
(\mathbf{n = 1 0 )}\end{array}$ & $\begin{array}{l}\text { Group II } \\
\mathbf{( N = 2 5 )}\end{array}$ & $\begin{array}{l}\text { Group III } \\
(\mathbf{N}=\mathbf{2 0})\end{array}$ & $\begin{array}{l}\text { Group IV } \\
(\mathbf{n = 1 5})\end{array}$ & Fc & CL \\
\hline $\begin{array}{l}\text { Duration of } \\
\text { hospital stay } \\
\text { (hours) }\end{array}$ & - & $6.5 \pm 2.1$ & $36.2 \pm 12^{\boldsymbol{\epsilon}}$ & $72 \pm 24^{\boldsymbol{\epsilon}}$ & 100 & 8.05 \\
\hline
\end{tabular}

The data represented as mean $\pm S D$ (standard deviation), $F c=$ calculated variance ratio by, $F t=$ tabulated variance ratio $=3.732, C L=$ confidence limit. ${ }^{\epsilon} P<0.05=$ significant difference compared with (group II). ${ }^{\#} \mathrm{P}<0.05=$ significant difference compared with (group III). 
Table 10: Percentage of outcome (recovery, morbidity and mortality) among scorpion stung patients groups II (mild grade), group III (moderate grade), group IV (severe grade) and the control group (group I).

\begin{tabular}{|l|l|l|l|l|}
\hline & $\begin{array}{l}\text { Group I } \\
(\mathbf{n = 1 0 )}\end{array}$ & $\begin{array}{l}\text { Group II } \\
\mathbf{( N = 2 5 )}\end{array}$ & $\begin{array}{l}\text { Group III } \\
\mathbf{( N = 2 0 )}\end{array}$ & $\begin{array}{l}\text { Group IV } \\
(\mathbf{n}=\mathbf{1 5})\end{array}$ \\
\hline Recovery & - & $25(100 \%)$ & $20(100 \%)$ & $15(100 \%)$ \\
\hline Morbidity & & 0 & 0 & 0 \\
\hline Mortality & & 0 & 0 & 0 \\
\hline
\end{tabular}

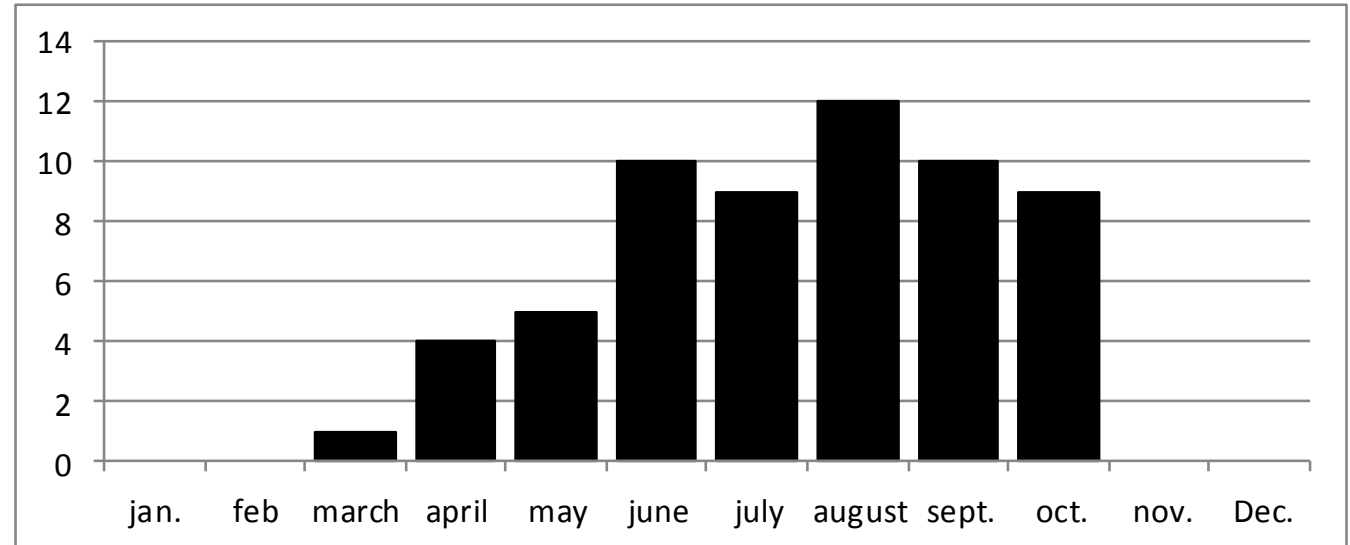

Histogram 1: The number of scorpion envenomated patients admitted from January to December 2015.

\section{Discussion}

Scorpion envenomation is a common medical health problem and a life-threatening hazard in many areas of Egypt. In the present study the type of involved scorpion could not be identified. The majority of stings in all groups (98.3\%) occurred between April and October. It is well established that scorpion envenomation is more frequent in the summer (Wesam and Khadega, 2013).

According to Nouira et al. (2007) envenomated patients were classified to three grades of increasing severity. In grade I (benign envenomation) pain is immediate, intense and persistent with feelings of partial recovery and relapse. The passage to the following grades is generally un-predictable and rapid. Grade II included envenomation with systemic manifestations. After the sting, in $10 \%$ of grade II cases, entry in the next grade often occurs between 4-12 hours. Grade III included very severe envenomation. At this stage, the risk of cardiovascular collapse is the highest, associated with major respiratory complications: pulmonary edema, bronchospasm, and cyanosis. At this stage, the evolution can be fatal in a few hours, sometimes in a few minutes. In young children, envenomation can evolve directly from grade I to III.

In the present study, patients in the severe group (group IV) were significantly younger and had lower body weight when compared with patients in the moderate (group III) and mild groups (group II).

Previous retrospective studies had confirmed the relation between young age and low body weight with the severity of clinical manifestations after scorpion envenomation. Moreover, cardio-respiratory manifestations, mainly cardiogenic shock and pulmonary edema, are more frequent in younger children and multiple organ failure has been reported (Bosnak et al., 2009; Mohamad et al., 2014). In (2010), Bahloul et al. observed that the serum levels of venom were higher in children than in adult patients with the same quantity of injected venom. It was explained by the rapid toxin absorption, extensive distribution from blood to tissues, small body mass and slower elimination in children compared with adults. Moreover, it is possible that in children, there is higher uptake in the heart and other organs.

The delay time was significantly longer in the severe group when compared with mild and moderate groups. This finding is in line with the study of Bahloul et al. (2010) who found fewer complications after envenomation in children group with shorter delay time. They explained their results as the venom rapidly distribute in the extravascular compartment so the symptoms usually appear early.

The most common local manifestation observed include severe pain at sting site. Furthermore, general manifestation as sweating, 
fever, cold extremities observed in moderate and severe groups. While, tachypnea, cyanosis and pulmonary edema, hypertension, tachycardia, heart failure, agitation, coma, vomiting, and abdominal pain were more common in the severe group. This was in accordance with previous studies by (Bosnak et al., 2009; Ahmed et al., 2015).

The intense pain induced by scorpion sting is a frequent clinical manifestation due to a paininducing peptide (BmP01) detected in the venoms of scorpion (Hakim et al., 2015).

The systemic manifestations of scorpion envenomation are as a result of massive release of catecholamines leading to activation of both sympathetic and parasympathetic nervous systems (Ahmed et al., 2015). Several studies have emphasized the effects of pro-inflammatory cytokines that cause fever and other systemic symptoms. Moreover, other investigators have suggested hypertensive encephalopathy, hypoxia, and a direct effect to the venom as the major mechanisms of agitation (Ladjel-Mendil et al., 2013 ; Taibi-Djennah et al., 2015).

In the present study, significant increase of glucose level was found in groups III and IV when compared with the control group and was significantly greater in group IV when compared with group III. CK-MB levels were significantly increased in group IV. These results are in agreement with many previous retrospective studies and hyperglycemia was considered as a poor prognostic factor associated with heart failure in severe cases (Bahloul et al.,2010; Agrawal et al.,2015 ; Ahmed et al.,2015)..

The pathogenesis could be explained by the autonomic storm occurred secondary to envenomation. A massive release of catecholamines, angiotensin II, renin, glucagon, cortisol, thyroid hormone and decreased insulin secretion. This causes a syndrome of energy insufficiencies, which leads to myocardial damage, pulmonary edema and hyperglycemia. Furthermore, scorpion venom involves the activation of the inflammatory response with the release and activation of pro-inflammatory cytokines and other mediators, such as nitric oxide (NO), which plays an important role in the regulation of blood vessels tone and subsequently the organ blood flow. Increased NO production may contribute to hypotension (Bouaziz et al., 2008; Ahmed et al., 2015). In addition, scorpion venom may affect voltage-gated sodium and potassium channels and causes myocardial ischemia with rise of cardiac enzymes (Miranda et al., 2014; Agrawal et al., 2015).

As regards the haematological parameters, a significant increase of total WBC and platelet counts was found in groups III and IV when compared with the control group and they were significantly greater in group IV compared with group III. In addition, Platelet counts showed a significant positive correlation with mean total WBC count and CK-MB levels. WBC count also positively correlated with CK-MB level in severe cases group.

Previous studies have reported that leukocytosis is a significant laboratory finding of systemic scorpion envenomations and it was associated with a poor outcome (Amucheazi and Umeh, 2012; Konca et al., 2014).

The study of Çağlar et al. (2015) revealed a significant increase of platelet count in the severely envenomated patients. In contrary, Bosnak et al. (2009); Mohseni et al. (2013) and Konca et al. (2014) found insignificant difference between scorpion envenomated cases and control as regards platelet count.

According to Ladjel-Mendil et al. (2013) and Taibi-Djennah et al. (2015), the signs of severe envenomation are related to an excessive systemic host inflammatory response to venom. Mediators affecting inflammatory processes, including interleukin-6, thrombopoietin, interleukin- 1, interleukin-4, interferon $\gamma$, and tumour necrosis factor- $\alpha$ and platelet activating factor may be released after scorpion envenomation. Moreover, the $\alpha$-adrenergic receptor on platelet surface can be stimulated by the released corticosteroids and adrenaline (Sulai and Tefferi, 2012). Platelets, in addition to their function in haemostasis, play an important role in the inflammatory process. It initiates and supports the inflammatory processes by secretion of numerous biologically active substances such as platelet activation factor, platelet-derived growth factor, platelet factor 4, IL1 and beta-thromboglobulin (Trzeciak-Ryczek et al., 2013). The results of this study further support that platelets are activated in severe scorpion envenomated cases and it is a high-grade inflammatory disease.

\section{Conclusion}

Increased levels of on admission glucose, CK-MB, total WBC and platelets count were more obvious in severely envenomated cases. Increased platelet, total WBC count and CK-MB level were found to be predictors of severe envenomation. So it is recommended to use these simple, broadly accessible and affordable tests to identify most vulnerable patients after scorpion envenomation thus helping early recognition of severity and administration of adequate treatment to prevent complications.

\section{References}

Agrawal A, Kumar A, Consul S, and Yadav A (2015): Scorpion bite, a sting to the heart. Indian J Crit Care Med. 19(4):233-6.

Ahmed AE, Abdel-Baseer KA, Saad K, Hassan AF and El-Houfey AA (2015): Endocrinological and biochemical changes of scorpionism in children in 
Upper Egypt. Ther Adv Endocrinol Metab. 6(5):210-6.

Amucheazi AO and Umeh BU (2012): Scorpion sting pain: which way to treat? Niger J Clin Pract.15:93-4.

Bahloul M, Chaari A, Dammak H, Samet M, Chtara K, Chelly H, Ben Hamida C, Kallel H and Bouaziz M (2013): Pulmonary edema following scorpion envenomation: mechanisms, clinical manifestations, diagnosis and treatment. Int J Cardiol. 162(2):86-91.

Bahloul M, Chabchoub I, Chaari A, Chtara K, Kallel H, Dammak H, Ksibi H, Chelly H, Rekik N, Ben Hamida C and Bouaziz M (2010): Scorpion envenomation among children: clinical manifestations and outcome (analysis of 685 cases). Am J Trop Med Hyg. 83(5):1084-92.

Bosnak M, Ece A, Yolbas I, Bosnak V, Kaplan M and Gurkan F (2009): Scorpion sting envenomation in children in southeast Turkey. Wilderness Environ Med.20(2):118-24.

Bouaziz M, Bahloul M, Kallel H, Samet M, Ksibi H, Dammak H, Ahmed MN, Chtara K, Chelly H, Hamida CB and Rekik N (2008): Epidemiological, clinical characteristics and outcome of severe scorpion envenomation in South Tunisia: multivariate analysis of 951 cases. Toxicon. 52(8):918-26.

Çağlar A, Köse H, Babayiğit A, Öner T and Duman M (2015): Predictive Factors for Determining the Clinical Severity of Pediatric Scorpion Envenomation Cases in Southeastern Turkey. Wilderness Environ Med. 26: 451-458.

Canter CE and Simpson KP (2014): Diagnosis and treatment of myocarditis in children in the current era. Circulation.129:115-128.

Cupo P (2015): Clinical update on scorpion envenoming. Rev Soc Bras Med Trop. 48(6):642-9.

Hakim MA, Jiang W, Luo L, Li B, Yang S, Song Y and Lai R (2015): Scorpion Toxin, BmP01, Induces Pain by Targeting TRPV1 Channel. Toxins (Basel). 14;7(9):3671-87.

Hartman ME and Cheifetz IM (2011): Pediatric emergencies and resuscitation. In: Nelson Textbook of Pediatrics. Kliegman RM and EmersonW (eds). 19 ${ }^{\text {th }}$ ed., Philadelphia, PA:Elsevier/ Saunders;PP279-295.

Kaplan LA (1984): Glucose. In: Clinical Chemistry, Louis S (ed.), Mosby Co.,Toronto, PP: 1032-1036.

Konca C, Tekin M, Colak P, Uckardes F and Turgut M (2014): An overview of platelet indices for evaluating platelet function in children with scorpion envenomation.

EXCLI J. 13:801-8.

Ladjel-Mendil A, Martin-Eauclaire MF and Laraba-Djebari F (2013): Neuro-pathophysiological effect and immunoinflammatory response induced by kaliotoxin of androctonus scorpion venom. Neuro-immunomodulation. 20(2):99-106.

Lawrence M and Robert HC (1993) :Methods of determination of blood urea nitrogen and serum creatinine, In :Tietz textbook of clinical chemistry, $2^{\text {nd }}$ edition , WB Saunders Company ,London , pp.621.

Mair J, Artner-Dworzak E, Dienstl A, Lechleitner P, Morass B, Smidt J, Wagner I, Wettach C and Puschendorf B (1991): Early detection of acute myocardial infarction by measurement of mass concentration of creatine kinase-MB. Am J Cardiol.68:1545-1550

Miranda CH, Maio KT, Moreira HT, Moraes M, Custodio VI, Pazin-Filho A and Cupo $\mathrm{P}$ (2014): Sustained Ventricular Tachycardia and Ca rdiogenic Shock due to Scorpion Envenomation. Case Rep Med. 251870.

Mohamad IL, Elsayh KI, Mohammad HA, Saad K, Zahran AM, Abdallah AM, Tawfeek MS and Monazea EM (2014): Clinical characteristics and outcome of children stung by scorpion. Eur J Pediatr. 173(6):815-8.

Mohseni A,Vazirianzadeh B, Hossienzadeh M, Salehcheh M, Moradi A and Moravvej SA (2013): The roles of some scorpions, Hemiscorpius lepturus and Androctonus crassicauda, in a scorpionism focus in Ramhormorz, southwestern Iran. J Insect Sci.13:89.

Nouira S , Boukef R , Nciri N , Haguiga H , Elatrous S, Besbes L, Letaief $M$ and Abroug F (2007): A clinical score predicting the need for hospitalization in scorpion envenomation . Am J Emerg Med. 25: $414-419$.

Reith FC, Van den Brande R, Synnot A, Gruen R, Maas AI (2016): The reliability of the Glasgow Coma Scale: a systematic review. Intensive Care Med. 42(1):3-15.

Rothrock SG, Green SM, McArthur CL and DelDuca K (1997): Detection of electrolyte abnormalities in children presenting to the emergency department: a multicenter, prospective analysis. Detection of Electrolyte Abnorm alities in Children Observational National Study (DEACONS) Investigators. Acad Emerg Med. 4(11):1025-31. 
Suber RL (1994): Clinical pathology methods for toxicology. In: Principles and methods of toxicology. Hayes AW,(ed), $3^{\text {rd }}$ ed., Raven press, New York, pp:476-96.

Sulai NH and TefferiA (2012): Why does my patient have thrombocytosis? Hematol Oncol Clin North Am. 26:285-301.

Taylor JK (1990): statistical technique for data analysis. $2^{\text {nd }}$ ed. Lewis Pub. Inc. USA. P.25-30.

Taibi-Djennah Z, Matin-Eauclaire MF and LarabaDjebari F (2015): Systemic Responses following Brain Injuries and Inflammatory Process Activation Induced by a Neurotoxin of Androctonus Scorpion Venom. Neuroimmuno-modulation. 22(6): 347 - 57.

Trzeciak-Ryczek A, Tokarz-Deptuła B and Deptuła W (2013): Platelets-an important element of the immune system. Pol $\mathrm{J}$ Vet Sci.16:407-13.

Wesam MS and Khadiga MS (2013): Surveillance study on scorpion species in Egypt and comparison of their crude venom protein profiles. The Journal of Basic \& Applied Zoology. 66, 76-86.

\section{الاملخص العربي}

بعض المعايير الكيميائيه الحيويه كأداه بسيطه للتنبؤ بشدة التأثر بسم العقرب بين بعض الاطفال المصريين

\section{جيهان بشري عزب و اجلال حسن العوضي}

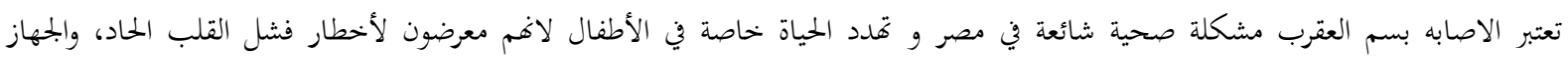

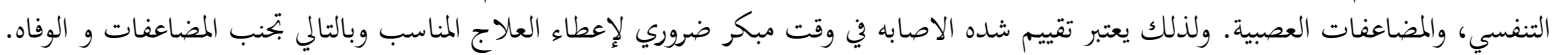

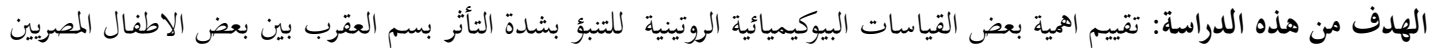

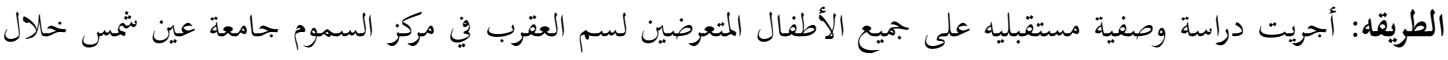

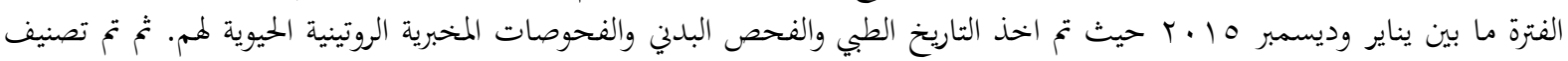

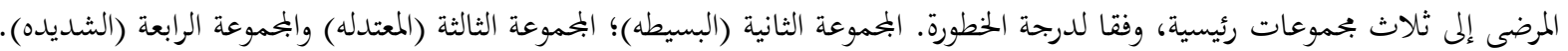

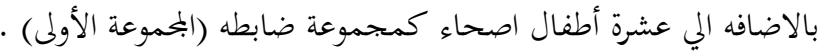

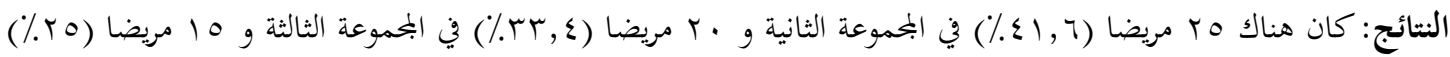

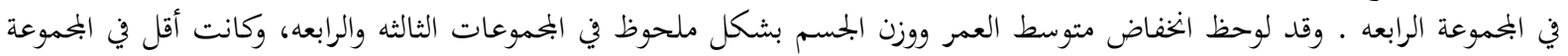

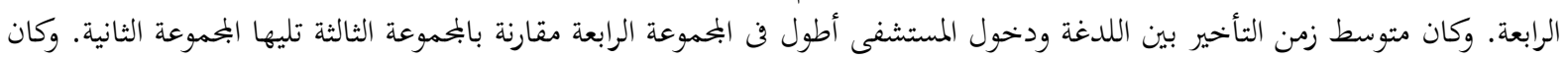

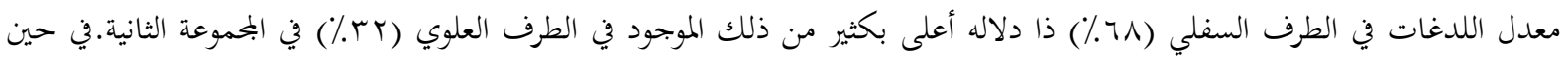

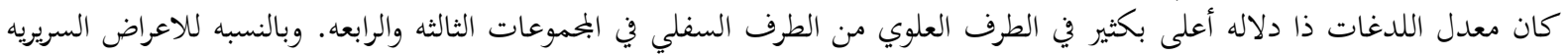

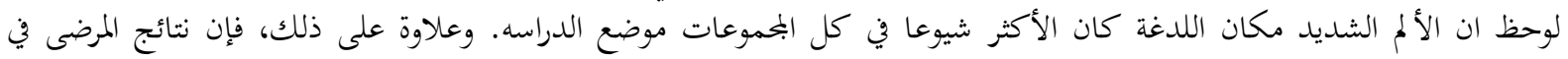

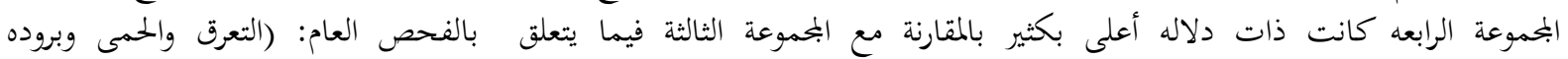

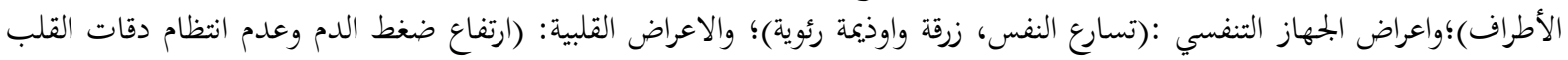

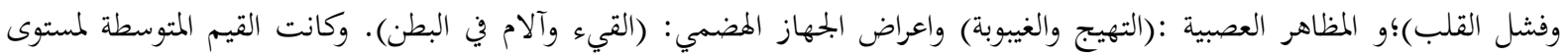

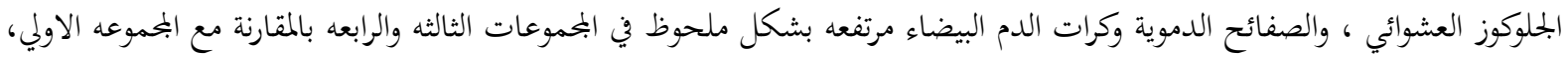

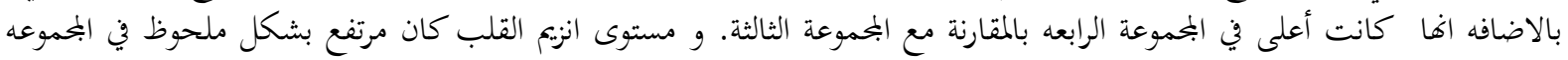

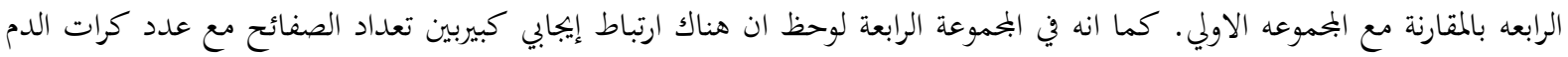

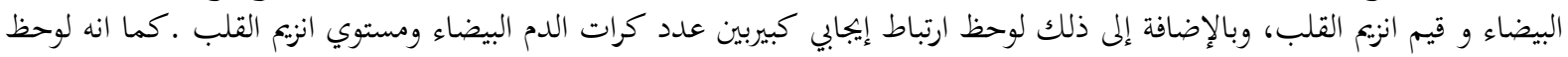

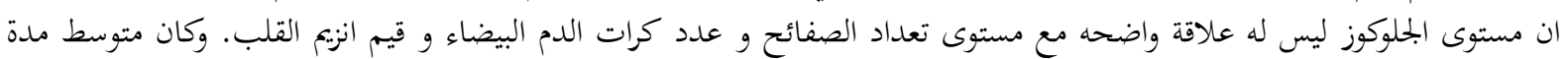

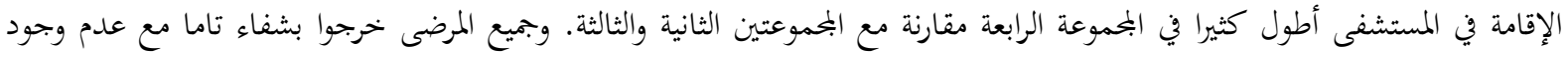
مضاعفات أو وفاة.

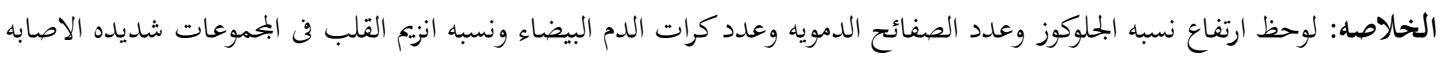

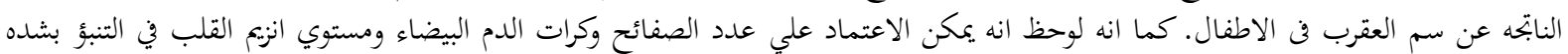
الاصابه. 